\title{
精製ふ、括ろもわくちんト原ふ扣るも わくちん卜ノ免疫比較試驗
}

\author{
大阪實驗治療研究所 (所長 目黑博士) \\ 學士 美濃葚澄
}

\section{【内 容抄 錄】}

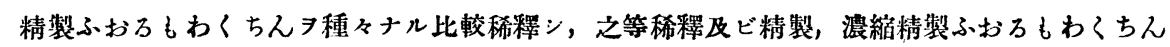
ト原ふおるもわくちんトヨ使用シテ其ノ挽疫能力习比較實驗シ，更二之等ふればらーきノ「Lf」 ト免度價トノ關保习寡羷考察セリ。

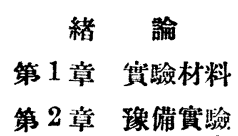

第 2 章 像備赛驗
目
次

第 3 章 實驗成績

第 4 章 結 論

\section{緒 \\ 緒論}

ぢふてりーふおるもわくちんノ精製，目的八免疫能力增强卜萊雜物（異種蛋白）除去二存 スルハ言キ俟タズ. 而シテ異種蛋白除去八化學的檢查ニヨリ判然ト之ヨ明示シ得ルモ, 抗原 能力八㙫强如何八簡單二之レタ決定シ得ザルモノナリ。

抑モ精製ふおるもわくちんタルト普通ふおるもわくちんタルトチ問ハズ，其，免疫價测定

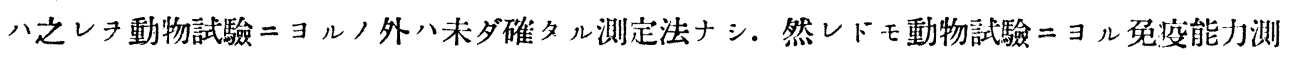
定二於テモ，亦動物個性，差異ノアルアリテ大ニ之レキ考虑セザルベカラズ. 故二該法=ヨ ル抗原测定二於テモ如上，理山二徵シテ試驗動物フ多數二使用シテ，所謂大數觀察フ要スヘ キナリ.

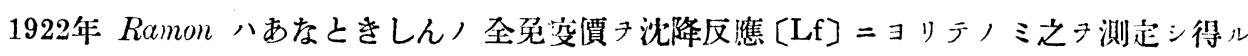
モノナリト發表七り．沈降價卜免疫價卜ハRamon，主張入ルガ如ク，果シテ一致入ルモ， ナルヤ否ヤノ買否八之タ姑ク置クモ沈降反應ナルモノ八ぢふててり一毒素ト同名抗毒素間， „Spezifische Neutralisation”ナル八嚴然タル事實ナリ．從ツテRamon，「Lf」ナルモノ八

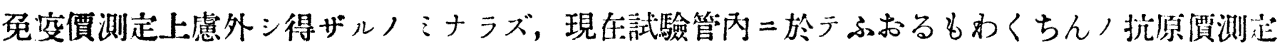
ニ於ケル唯一, 方法タリ。

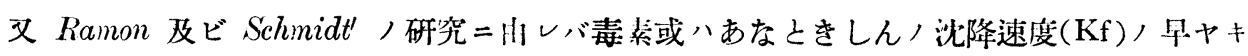

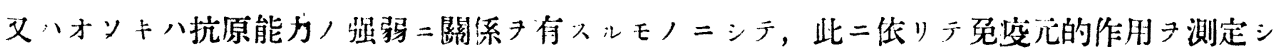




美浱暻澄述

得ルモノナルコトタ信ゼリ・又Krauダ如上ぷれぱらーとノ抗原能力斗動物僰內二於ヶル 毒素抗毒会，結合能力⿻コ一試驗スルコトニ由リテ檢出スルコトタ得ベシト主張シタリ。

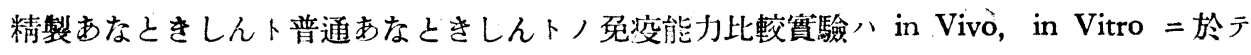
種タナル方法二依り施行セラレ報告サレタリ.

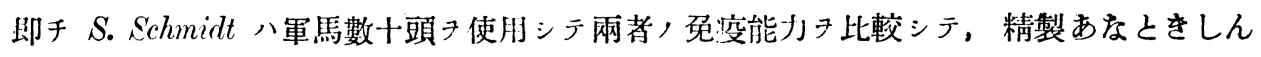
ノ優秀ナル事キ報告シ. 又 Tasman, 細谷, 宮田, 古賀及ビ著者等八海猽, 免变比較實驗= 依り，精製ふおるもわくちんノ免疫能力强大ナルコトタ報告セリ・

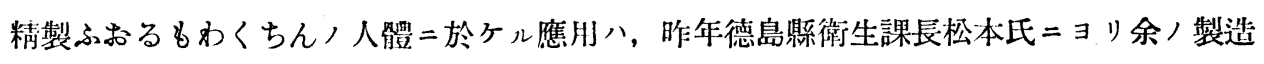
七ルぷぱらーとヨ使用シ，しつく陽性兒二實驗セラレ精製ふおるもわくちん 2 回性射二ヨ

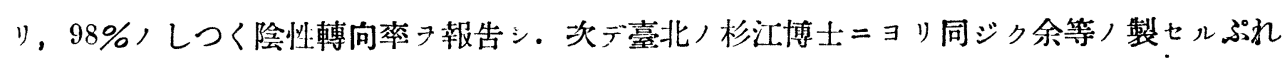
ぱらーとヌ使用シ。しつく陽性兒，陰性轉向率尹檢七シ二精製ふおるもわくちん八 $93,7 \%$, 普通わくちんハ $71.5 \%$ ，實驗成績尹最近報告七ラレタリ（但シ杉江博士しつく再檢桿八 わくちん注射後30日後二於テ施行七ラレタルモノナル故二, 之760日後二於テ䉆サレタルモ ノナラバ更二好成績キ得タルモノナラン).

其, 他 in Vitro 二於テ兩者子此較七ルモノ Ramon, Tasman 及ど著者ノモノアリ.

然レ共如上，諸實驗ノ多ク八精製ふおるもわくちん卜普通ふおるもわくちんト八同一系統 ニアラズ，換言七バ精製ふおるもわくちん卜其ノ源タル普通ふおるもわくちんノ比較ニアラ ザルナリ．唯余ハ 1 昨年同一系统ノ精製並二原ふおるもわくちん, 數種, 㣻㴭比較試驗子報 告七ルモ，其八表面的比較實驗ニシラ斷面的比較實驗ニアラザルナリ. 即子今若三精製並二 原ふおるもわくちんノ乔疫比較二際シ，精製ふおるもわくちんす數種二稀釋シテ該稀釋精製 ふおるもわくちんト原ふおるもわくちんト比較セバ，原及ビ精製ふおるもわくちん，關係，

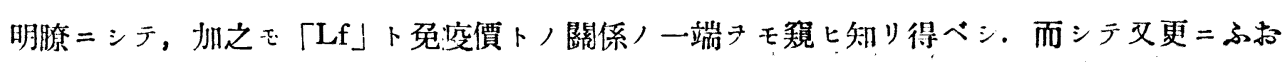
るもわくちん精製, 意義モ明示サルルモノニ似タリ.

\section{第 1 童 實 驗材 料}

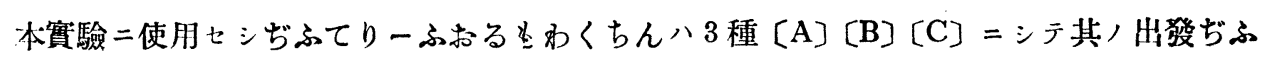

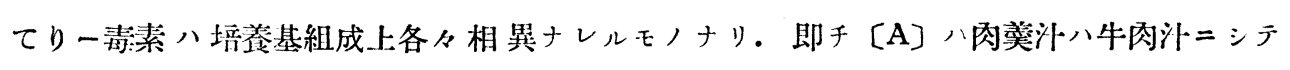
Pepton 八所謂活性ぺぷとん. [B] 八仔牛肉汒卜活性ぺぷとんヨリ組成七ラレ, [C]八牛肉 汒卜 Witte $=$ Pepton トヨリ組成七ラレタルモノナリ. 以上 3 培食基トモ Stamm 八同一 シテ William=Parks No. 8 ニシテぢふてりー毒素中凡テ $1 / 500=\mathrm{DLM}$ 以上ノモノナリ.

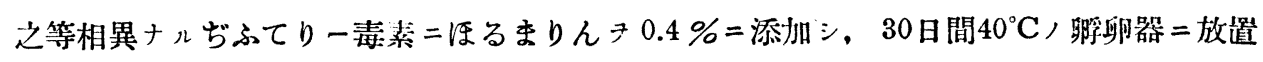
シタル後，齐 $5 \mathrm{cc} 73$ 匹, 海猽，腹部皮下二注射三無毒化七几フ檢定七シモノナリ， 
如上ノ相異ナル 3 種 [A] [B] [C] ぢふてりーふおるもわくちんき Taoman 氏法ニョリ 精製七リ.

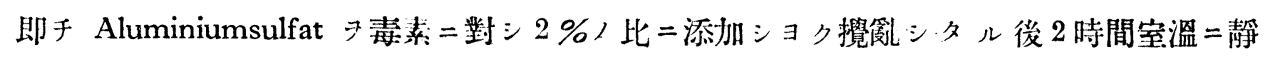

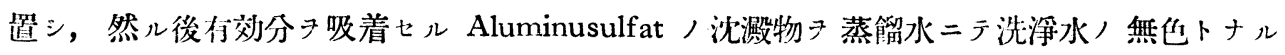
迄水洗 シ。該水洗澱物 $710 \%$ 燐酸曹達液 $200 \mathrm{cc}$ (ふ小るもわくちん $1000 \mathrm{cc}=$ 對シテ ) $=24$ 時 間浸漬シテ.之フ滤過シタル滤液が所謂精製ふおるもわくちんナリ。

而シテ (A), (B), (C) 3 種ノふ扮るもわくちんノ精製及ビ獲得度八第 1 表二示スが如シ. 第 1 表

\begin{tabular}{|c|c|c|c|c|c|c|c|c|c|c|c|c|}
\hline $\begin{array}{l}\text { 小ढ } \\
\vdots わ \\
3<\end{array}$ & $\begin{array}{l}\text { 原 ふお } \\
\text { Volum }\end{array}$ & P. $\mathrm{H}$ & $\begin{array}{l}\text { もわ } \\
\mathrm{AW}\end{array}$ & $\begin{array}{c}\text { ち } \\
\mathrm{Nin} \\
100 \mathrm{cc}\end{array}$ & $\frac{\mathrm{AW}}{\mathrm{N}}$ & Volum & $\begin{array}{l}\text { 製 } \\
\text { P. H }\end{array}$ & $\begin{array}{l}\text { ふお } \\
\mathrm{AW}\end{array}$ & $\begin{array}{c}\zeta \quad b \\
\underset{100 \mathrm{cc}}{\mathrm{Nin}}\end{array}$ & $\begin{array}{l}\text { わ } \\
A W \\
\mathrm{~A}\end{array}$ & $\begin{array}{l}5 \\
\text { 精 } \\
\text { 製 } \\
\text { 度 }\end{array}$ & $\begin{array}{l}\text { 人 } \\
\text { 獲 } \\
\text { 得 } \\
\text { 度 }\end{array}$ \\
\hline A & $1000 \mathrm{cc}$ & 7.8 & $\begin{array}{l}5 \mathrm{AE} \\
(0.1)\end{array}$ & 0.2866 & 10.4 & $200 \mathrm{cc}$ & 7.7 & $\begin{array}{c}15.0 \mathrm{AE} \\
(0.06)\end{array}$ & 0.0724 & 205.9 & 19.8 & $50 \%$ \\
\hline B & $1000 \mathrm{cc}$ & 8.0 & $\begin{array}{l}6 \mathrm{AE} \\
(0.12)\end{array}$ & 0.3012 & 19.2 & $200 \mathrm{cc}$ & 7.8 & $\begin{array}{c}25.0 \mathrm{AE} \\
(0.1)\end{array}$ & 0.0866 & 238.8 & 15.0 & $83 \%$ \\
\hline $\mathrm{C}$ & $1000 \mathrm{cc}$ & 7.8 & $\begin{array}{l}2.5 \mathrm{AE} \\
(0.05)\end{array}$ & 0.2656 & 9.0 & $200 \mathrm{cc}$ & 7.8 & $\begin{array}{c}12.5 \mathrm{AE} \\
(0.05)\end{array}$ & 0.0752 & 166.2 & 19.4 & $100 \%$ \\
\hline
\end{tabular}

表中 „AW”八,Antigenwert”，意ニテ Ramon，沈降反應ニョリテ测定七ル „Lf”，單

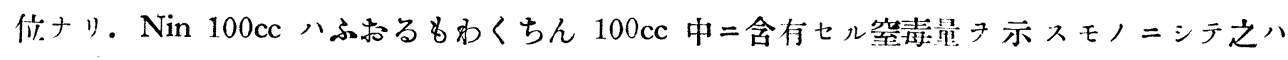
Kjeldahl 法ニヨリ测定七リ. 而シテ精製ふおるもわくちんハ凡テ1/\%二濃縮七ラレタルチ以ッ テ其, 全空素量八 A，B，C，共 $95 \%$ 以上除去七ランタル譯ナリ、獲得度八表示七ルガ如

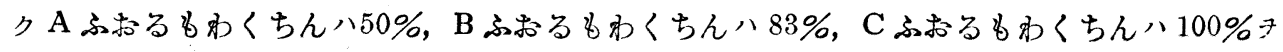
示セり.

而シテ免疫二使用セ儿ふおるもわくちん八表示ノ 12 ふれぱら一と即于

I A原ふおるもわくちん=[A] $(5.0 \mathrm{AE})$

II B原ふおるもわくちん=[B] $(6.0 \mathrm{AE})$

IC原ふおるもわくちん=[C] $(2.5 \mathrm{AE})$

III $\mathrm{A} ヨ$ リノ精製濃縮ふおるもわくちん=GR[A] (15AE)

V B ヨリノ精製濃縮ふおるもわくちん=GR [B] (25AE)

VI Cョリノ精製濃縮ふおるもわくちん=GR[C] (12.5AE)

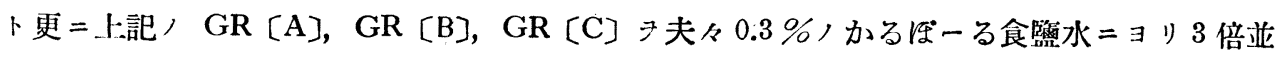
$=5$ 倍二稀釋七ルぷれぱらーと6 種類即于

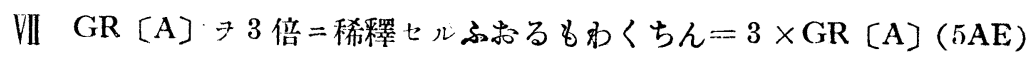




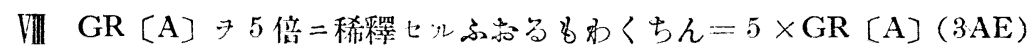

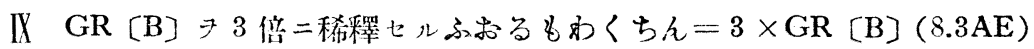

$X \mathrm{GR}[\mathrm{B}] \ni 5$ 倍二稀釋七几ふおるもわくちん= $5 \times \mathrm{GR}$ [B] (5.0AE)

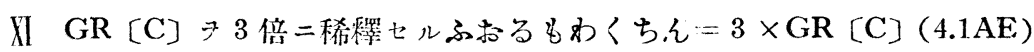

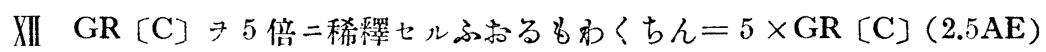

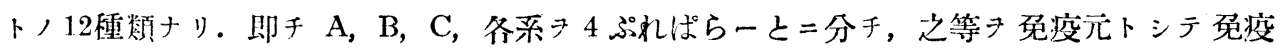
能力尹比較考查セルモノナリ。

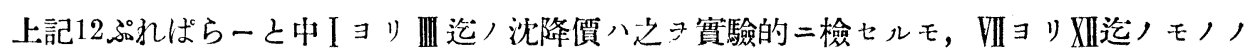
沈降價八實驗的二求ム几迄モナク數理的二求×ラルルモノナリ. 即于 3 倍二稀粰七几モノ八

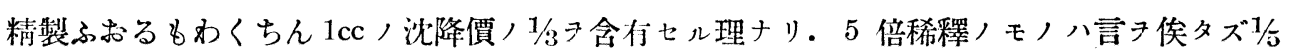
ヨ们セルナリ.

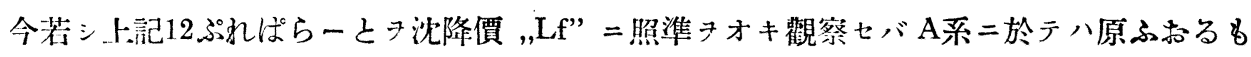

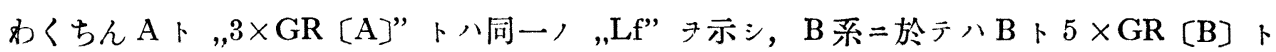
殆ド一致シ，C系二於テハCト $5 \times \mathrm{GR}[\mathrm{C}]$ 卜同一ノ沈降價习示七り。其，外異系=於テ見 ルナラバ $[\mathrm{A}] ト 5 \times \mathrm{GR}[\mathrm{B}]$ トモ同一， „Lf” タ示セリ.

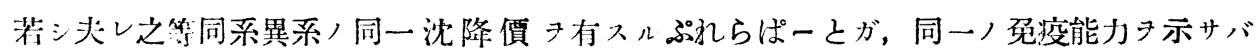
Ramon, „Lf = Antigenwert”ナル說ハ確認サルルモ, ナランカ.

\section{第 2 章 豫 備 實 驗}

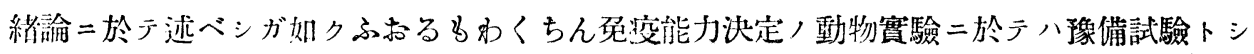
テ晋通海猽血清中，抗毒單位习测定七ザル可カラズ. 故二余八ふおるもわくちん注射二先立 チテ實驗海猽各 5 匹キ 1 群トナシ, 1 群中ノ各々ノ 上膊靜脈ヨリ $0.5 \mathrm{cc}$ 乃至 $1.0 \mathrm{cc}$ 採血シ，之 䈍, 血清タ混合シテ冬群ノ抗毒單位タ测定セリ。

而シテ血清中微量抗毒素單位测定法八目黑，末松氏家兔皮內反應ニヨレルモノナリ。

即于家鬼皮內法二於テハ「DLM」ヨ單位卜七ル種タナル階段的毒素量タ含メル毒素稀釋

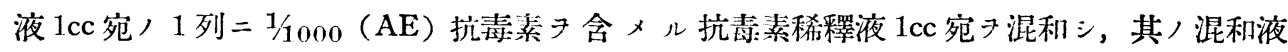

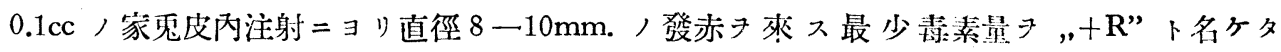

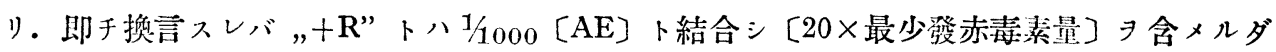

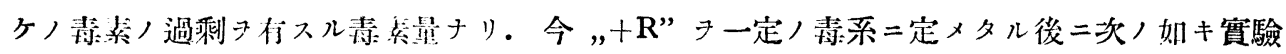
施行入.

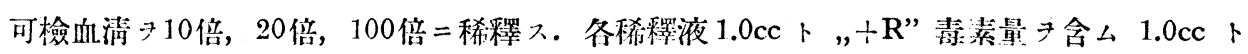




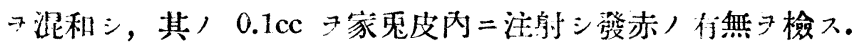

10倍稀釋血淸 $1 \mathrm{cc}+,+\mathrm{R}$ ”毒素量 $1.0 \mathrm{cc}+---$

20 倍稀釋血清 $1 \mathrm{cc}+,+\mathrm{R}$ ” 毒素量 $1.0 \mathrm{cc}++-$

100 倍稀釋血清 $1 \mathrm{cc}+,+\mathrm{R}$ ” 毒素量 $1.0 \mathrm{cc}+++-$

（但シ〔十〕八發赤キ〔一]八發赤來サザルモノ）

今若シ 3 稀釋血清全部が發赤キ來七シトキハ該可檢血清ハ $1 / 100 \mathrm{AE}$ 以下ノ抗青絲單位ナリ，

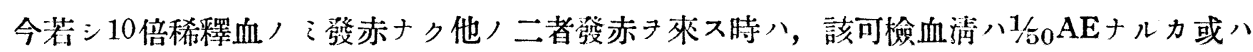
$1 / 100$ AE以上, 抗毒录單位ヨ示ス。

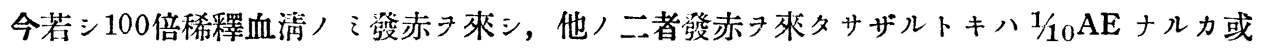
八 $1 / 50 \mathrm{AE}$ 以上, 抗毒委單位习示ス.

今若シ三者共發赤キ來タサザル時ハ $1 / 10$ AE以上ナリ.

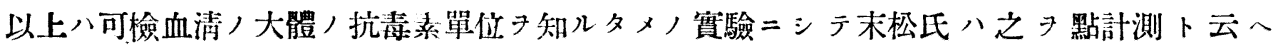
リ。

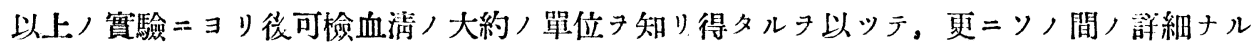

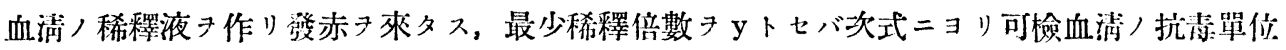
ヨ示スコトタ得.

可檢血活抗責單仿 $=-\frac{y}{1000}$

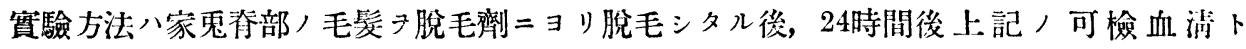

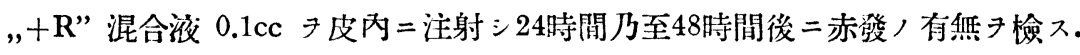

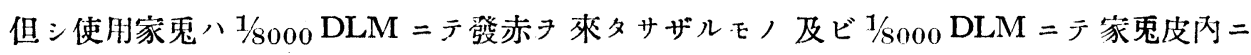
發赤タ起サシメ得ザル毒素八實驗二役立タザルモノうリ。

余ノ使用七シぢふてり一毒素八

$$
\left.\begin{array}{l}
\mathrm{DLM}=1 / 110^{\mathrm{cc}} \\
\mathrm{L}+=0.178 \mathrm{cc} \\
\mathrm{QL}=19 \\
\#+\mathrm{R}=1 / 48 \cdot 7 \text { (DLM) }
\end{array}\right\}, \leftleftarrows /+リ .
$$

上.述，目黑，末松法ニテ Normal，海猽 5 匹，混合血清 數十匹二涉りテ檢查七ル二，凡

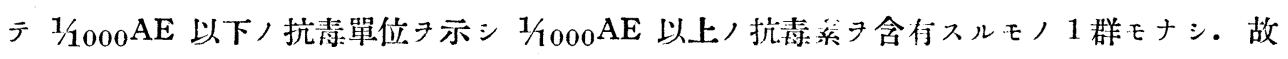
二别ニ之キ表示セズ.

\section{第 3 章 實 驗 成 績}

余八上述ノ A， B，Cノ 3 種ふおるもわくちん及ビ之ヨリ精製七几濃縮亚二稀釋精製ふお 


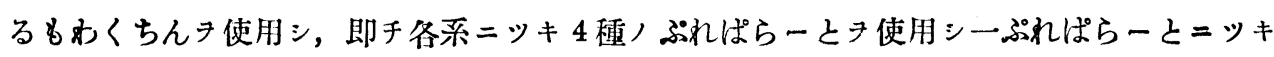
5 匹ノ海猽ヨ使用シ, 1 週間々隔ニテふおるもわくちん $0.5 \mathrm{cc}-1.0 \mathrm{cc}-1.5 \mathrm{cc}$ 注射シ, 最終注 射後 30 日目 $=5$ 匹全部 採血シ・ソレ等ノ血清タ混合シ該混合血清ノ抗毒素單位タ測定セリ. 抗素素單位測定八上述，目黑，末松家鬼皮內測定法ニヨレリ。

下記 3 表ニッキ精製濃縮, 精製稀釋, 及ビ原ふおるもわくちん, 乔疫能力ョ比較檢討スル 時, 第 1 顯著ナル事ハ1/5濃縮精製ふおるもわくちん八原ふおるもわくちん二比シ，凡テ一致 第 2 表 A系/實驗成績

\begin{tabular}{|c|c|c|c|c|}
\hline $\begin{array}{l}\text { ふおるも } \\
\text { わくちん }\end{array}$ & $\begin{array}{l}\text { 海㩧番號䖒 重 } \\
\end{array}$ & $\begin{array}{l}\text { ふおるもわく } \\
\text { ちん Lf (1cc) }\end{array}$ & 注射全量 & 抗毒單位 \\
\hline $\begin{array}{l}\text { A]ふおわ乃 } \\
\text { 孔わくちん }\end{array}$ & 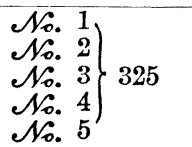 & $5.0 \mathrm{AE}$ & $3 \mathrm{cc}$ & $0.02 \mathrm{AE}$ \\
\hline $5 \times \mathrm{GR}[\mathrm{A}]$ & $\left.\begin{array}{c}\mathscr{N}_{0 .} 6 \\
\mathscr{N}_{0 .} \\
\mathscr{N}_{0 .} \\
\mathscr{N}_{0 .} \\
\mathscr{N}_{0.10} \\
\mathscr{N}_{0}\end{array}\right\} 308$ & $3.0 \mathrm{AE}$ & $3 c c$ & $0.01 \mathrm{AE}$ \\
\hline $3 \times \mathrm{GR}[\mathrm{A}]$ & $\left.\begin{array}{c}\mathscr{N}_{0.11} \\
\mathscr{N}_{0.12} \\
\mathscr{N}_{0.13} \\
\mathscr{N}_{0.14} .14 \\
\mathscr{N}_{0.15}\end{array}\right\} 307$ & $5.0 \mathrm{AE}$ & $3 \mathrm{cc}$ & $0.05 \mathrm{AE}$ \\
\hline$G R[A]$ & $\left.\begin{array}{l}\mathscr{N}_{0.16} \\
\mathscr{N}_{0} .17 \\
\mathscr{N}_{0} .18 \\
\mathscr{N}_{0} .19 \\
\mathscr{N}_{0.20}\end{array}\right\} 312$ & 15.0AE & $3 \mathrm{cc}$ & $0.2 \mathrm{AE}$ \\
\hline
\end{tabular}

第 3 表 B系, 實驗成績

\begin{tabular}{|c|c|c|c|c|c|}
\hline $\begin{array}{l}\text { ふおるる } \\
\text { わくちん }\end{array}$ & $\begin{array}{l}\text { 海 犋 } \\
\text { 年 }\end{array}$ & 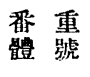 & Lf $(1 \mathrm{cc})$ & 注 射 量 & 抗毒素單位 \\
\hline $\begin{array}{c}\mathrm{B} \\
(\text { 原ふおうろ } \\
\text { わ(ちん) }\end{array}$ & $\left.\begin{array}{c}\mathscr{N}_{0.21} \\
\mathscr{N}_{0.22} \\
\mathscr{N}_{0.23} .23 \\
\mathscr{N}_{0.24} \\
\mathscr{N}_{0.25}\end{array}\right\}$ & 313 & $6.0 \mathrm{AE}$ & $3 \mathrm{cc}$ & $0.05 \mathrm{AE}$ \\
\hline $5 \times \mathrm{GR}$ (B) & $\begin{array}{r}\mathscr{N}_{0.26} \\
\mathscr{N}_{0.22} \\
\mathscr{N}_{0.28} .28 \\
\mathscr{N}_{0.29} \\
\mathscr{N}_{0.30}\end{array}$ & 321 & & $3 \mathrm{cc}$ & $0.05 \mathrm{AE}$ \\
\hline $3 \times$ GR (B) & $\left.\begin{array}{c}\mathscr{N}_{0.31} .31 \\
\mathscr{N}_{0} .32 \\
\mathscr{N}_{0.33} .33 \\
\mathscr{N}_{0.34} \\
\mathscr{N}_{0 .} .35\end{array}\right\}$ & 315 & 8.3AE & $3 \mathrm{cc}$ & $0.15 \mathrm{AE}$ \\
\hline GR (B ) & $\left.\begin{array}{r}\mathscr{N}_{0} .36 \\
\mathscr{N}_{0} .37 \\
\mathscr{N}_{0.38} .38 \\
\mathscr{N}_{0} .39 \\
\mathscr{N}_{0.40} \\
\end{array}\right\}$ & 315 & $25.0 \mathrm{AE}$ & $3 \mathrm{cc}$ & $0.6 \mathrm{AE}$ \\
\hline
\end{tabular}

シテ10倍/免度 カキ示シ.

第 $2=$ 八 3 倍 稀釋精製ふおる もわくちん八原 ふおるもわくち ん=比シ 2 倍牛 乃至 3 倍, 乔疫 能力キ示シ, 濃 縮ふおるもわく ちん二對シテ八 $1 / 4$ 乃至 $1 / 3$, 免疫 價 示セリ.

第 3 =著名ナ ル八 5 倍稀釋情 製ふおるもわく ちん即于原ふお るもわくちんト 同一容積二稀釋 七ルモノ八精製 , 際, 獲得度= ヨリ冬々免疫價 习異ニセリ. 即 于 $\mathrm{A}$ 系二於テ八 精製, 際, 獲得 
第 4 表 C系／實驗成績

\begin{tabular}{|c|c|c|c|c|}
\hline $\begin{array}{l}\text { 小おろ } \\
\text { わくん }\end{array}$ & 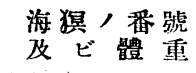 & Lf $(1 \mathrm{cc})$ & 注 射 量 & 抗埥素單位 \\
\hline $\mathrm{C}$ & $\left.\begin{array}{l}\mathscr{N}_{0.41} \\
\mathscr{N}_{0.42} \\
\mathscr{N}_{0.43} \\
\mathscr{N}_{0.44} \\
\mathscr{N}_{0.45}\end{array}\right\} 330$ & $2.5 \mathrm{AE}$ & $3 \mathrm{cc}$ & $0.015 \mathrm{AE}$ \\
\hline $5 \times \mathrm{GR} \quad[\mathrm{C}]$ & $\left.\begin{array}{l}\mathscr{N}_{0.46} \\
\mathscr{N}_{6.47} \\
\mathscr{N}_{0.48} \\
\mathscr{N}_{0.49} \\
\mathscr{N}_{0.50}\end{array}\right\} 323$ & $2.5 \mathrm{AE}$ & $3 \mathrm{cc}$ & $0.02 \mathrm{AE}$ \\
\hline $3 \times \mathrm{GR}[\mathrm{C}]$ & $\left.\begin{array}{c}\mathscr{N} .51 \\
\mathscr{A}_{0.52} \\
\mathscr{N} 0.53 \\
\mathscr{N}_{0.54} \\
\mathscr{N}_{0.55}\end{array}\right\} 315$ & $4.1 \mathrm{AE}$ & $3 r c$ & $0.05 \mathrm{AE}$ \\
\hline$G R[C]$ & $\left.\begin{array}{l}\mathscr{N}_{0.56} \\
\mathscr{N}_{0.57} \\
\mathscr{N}_{0 .} .58 \\
\mathscr{N}_{0.59} .59 \\
\mathscr{N}_{0.60}\end{array}\right\} 327$ & $12.5 \mathrm{AE}$ & $3 \mathrm{cc}$ & $0.15 \mathrm{AE}$ \\
\hline
\end{tabular}

度八 $50 \%$ ニララ 其八免疫價八原 ふおるもわくち ん'其レニ比シ $1 / 2$ 二減少七り。

精製濃縮ふお るもわくちん= 對シテハ $1 / 20$ ， 堍疫價习示ス 過ギザルナリ。

B系二於テ八 其, 獲得度八 83 \%ナリ。

而シテ 5 倍稀釋精製ふおるもわくちん八原ふおるもわくちんト同一）免疫能力テ示セリ。

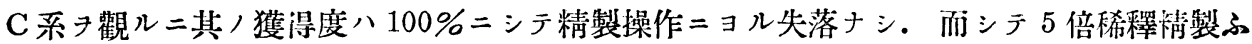
おるもわくちん八原ふおるもわくちんヨリ優秀ナル免疫價キ示セリ。

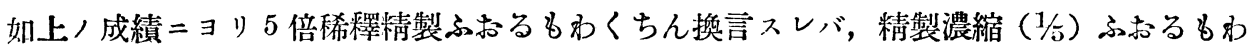

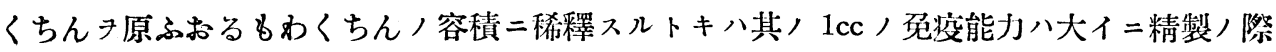
, 失落, 度ニヨリ左右七ラルルモノニシテ精製度二八關係セザルガ如シ。

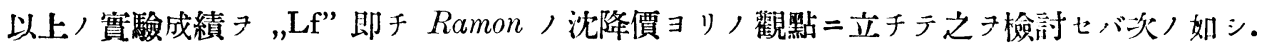

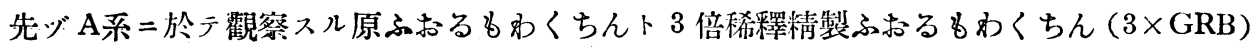

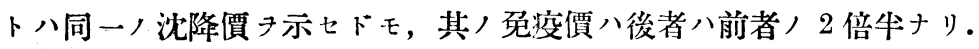

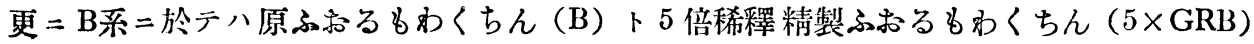
トハ殆ド同一，„Lf” タ示シ，其ノ冤疫價モ亦同價ナリ。

C系尹見ルニ原ふおるもわくちん（C）ト5倍稀釋清製ふおるもわくちんト八同價ノ沈降 仅應キ示スモ，其，免疫能力八 $0.005 \mathrm{AE} /$ 差キ示セリ。

更二異系ニ於テ同一，沈降價 キ示ス. A 原ふおるもわくちんト B 5 倍稀釋怗製ふおるもわ くちんト 比較スル二, 其)免疫能力八前者八後者， $1 / 2$ 以下ナリ．然レ共 3 倍稀釋精製ふお るもわくちん A $(3 \times \mathrm{GRA})$ ト 5 倍稀釋精製ふおるもわくちん B $(5 \times \mathrm{GRB})$ ト八同一）沈 降價及ビ同一)乔疫價キ示セル八興味ノ存スル所ナリ。

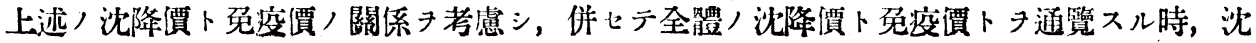




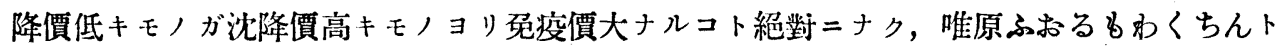

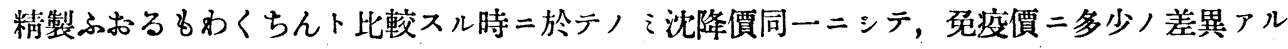

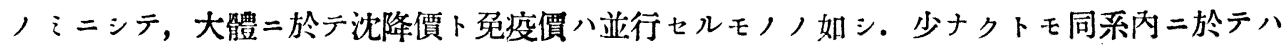
免疫價八沈降價 =比例七ルカ如三。

異系ニシテ此ノ事實存スルヤ否ヤ八唯如上 3 例 以以ッテ速斷ス可キニアラザルモノニシテ， 佾多數ノ實驗登列丹要ス可キモノト信ズ．晌此ノ點ニ關シテハ目下實驗中二付キ後日報告七 ントスルモノナリ。

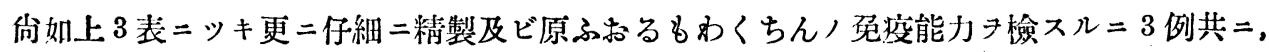

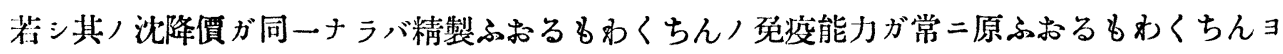

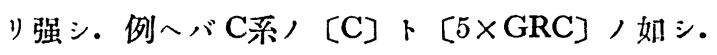

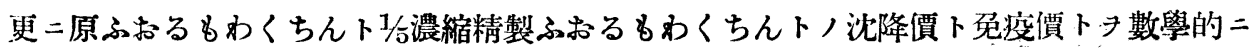
比較七バ次ノ如シ.

例へバ A系二於テ

原ふおるるわくちん (A) $3 \mathrm{cc} \times 5 \mathrm{AE}=15 \mathrm{AE}$

1/5精製涱縮ふ和るもわくちん（GRA）3cc $\times 15=45 \mathrm{AE}$

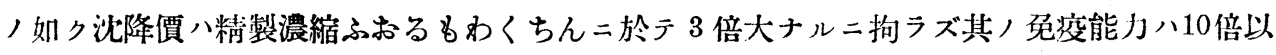

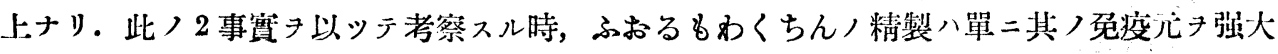
ナラシメ蛋白體キ除去セシメル,ミナラズ，乔疫能力フ障害セルが如キ物質タモ除去入ルモ

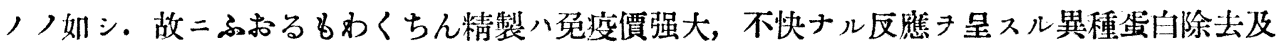
ビ色疫能力障害物質除去ノ 3 大意義ヨ有スルモノト信ズ。

\section{第 4 章 結論}

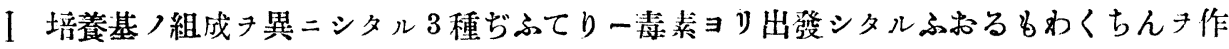

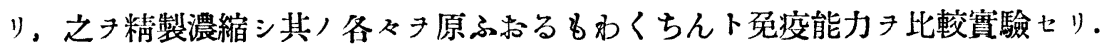

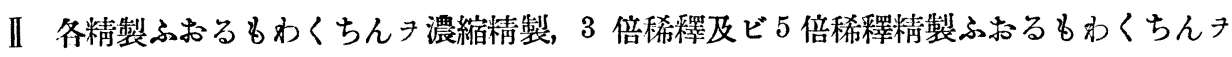

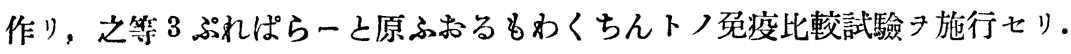

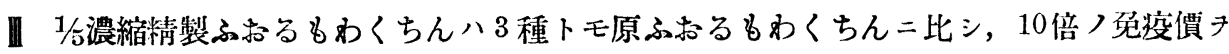
示セリ.

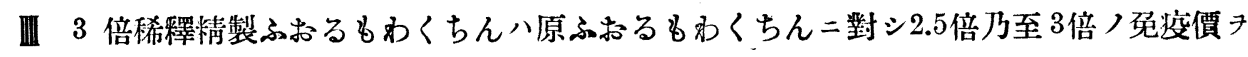
示セリ.

V 5 倍桸釋情製ふおるるわくちん八精製, 際ノ失落度ニョリ原ふおるもわくちん二對シ 
相異ナル冤疫能力キ示七り．即チ失落ナキモノ換言七バ100\%/獲得度ノモノ八，原ふおる

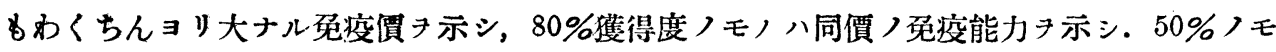
八 八 $1 / 2$ 八免度價习示セリ.

VI 沈降價 „Lf”ト免疫價卜八同一系二於テハ大體二平行スルモノノ如シ。但 シ數學的 二正比例スルモノニアラズ. 兩者ノ關係二相當, 開キアルモノナリ.

VII ふおるもわくちん精製八免疫能力强大卜異種蛋白除去以外二劣免遮障害物質 $[\times]$ キ モ除去スル作用アルモノノ如シ.

稿タ終ルニ臨ミ恩師目黑博士ノ指導ト校閱タ謹锹ス.

\section{主要 文 献}

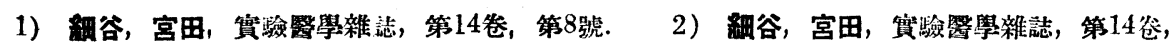
第10號. 3）细谷，日本傳染病學會，第7卷，第2號.

4) 䠐谷, 日本傅染病學會, 第7 兊, 第3 號. 5）古賀，東京醫事新誌，N秎 2309. 6) 美震, 日本微生物學病理學䆶誌, 第29卷, 第4諕. 7) 美浱, 日本微生物學病理學雜誌, 第29卷, 第9號, 8) 枟本, 日本 微生物學病理學雜誌, 第29卷, 第 5 號. 9）目黑, 末松, 甲斐, 日本微生物學病理學雜誌, 第29卷，第2號. 10） S.Schmidt : Zeitschrift für Inmŭnitätforschung Band 71.

11) Tasman u. Pondman : Zeitschrift für Immunität forschung Band 72.

Tasman u. Pondman : Zeitschrift für Immunität forschung Band 73 .

13) Jasman

u. Waasbergen : Zeitschrift für Immunität forschung Band 75 . 14) Tasman u. Wassbergen : Zeitschrift für Immünität forschung Band 76 .

15) Ramon : Immunität Allergie u. Infeutions uranuheit Band I. 